\title{
Research on the Influence of Summer Social Practice on Enhancement of Students' Comprehensive Qualities
}

\author{
Lu Li \\ School of Economics and Management, Jingchu University of Technology, Jingmen Hubei 448000 \\ China.
}

Keywords: Summer social practice; comprehensive qualities; college students.

\begin{abstract}
The period of studying in the college is very important for students. During this period, college students should accomplish the accumulation of much general and professional knowledge, and at the same time, they are expected to achieve great improvement in mental level, ability, thinking and cognition. Therefore, the comprehensive practical activities have an important impact on college students. In various kind of activities, summer social practice is particularly important, which is constantly being emphasized by the society, schools and families because of its great significance for the improvement of college Students' comprehensive qualities and abilities. Through the research about the summer social practice and improvement of students' comprehensive qualities, the author proposes targeted countermeasures for schools and students to form a good atmosphere of summer social practice, hoping to promote the social practice activities in summer vacation and personal ability development of college students.
\end{abstract}

\section{Introduction}

That colleges and universities organize students to participate in the social practice activities in summer vacation is consistent with the requirement in the new situation to cultivate talents with all-round abilities. Summer social practice is not only a kind of activities to develop ability but also a practice to test the comprehensive application of knowledge and ability in higher education; it is not only an important part of the development and deepening of higher education in the society with Chinese characteristics but also another way to implement China's education development policy. With the popularity of summer social practice, more and more students take part in activities of such kind. They enjoy the fun brought by work and dedication in these activities, which improves social productivity and helps to achieve the comprehensive development while putting the five-in-one education mode (all around development of moral, intellectual, physical, aesthetics and labor education) into practice. Because of the importance of summer social practice, more schools and institutions begin to deploy and implement summer social practice, which is believed to improve the overall quality of college students.

\section{The Significance of Summer Social Practice for the Promotion of College Students' Comprehensive Qualities}

\subsection{The Development of Summer Social Practice for College Students is Beneficial to Their Self-Development.}

It is a very good opportunity for students to take part in the social practice activities in summer vacation because they can cultivate the students' positive, optimistic and pure thoughts and personality. Summer social practice can also exercise college students' comprehensive abilities, such as language expression, interpersonal skills, and so on. The communication and interaction with classmates and other people, in particular, can not only cultivate their compassion and love, but can also help them to improve their interpersonal skills and promote their creativity in practice [1]. 


\subsection{The Development of Summer Social Practice for College Students Enriches the Construction of Campus Culture.}

Because of its diversified forms and enjoyable contents in activities, social practice is of great significance for enriching the college students' extracurricular life in the actual construction and development process. It is necessary to cultivate students' sense of social responsibility and mission, so as to expand the moral, physical and aesthetic education in colleges and universities to the society. 2.3. The Development of Summer Social Practice for College Students is Conducive to Building a Harmonious and Healthy Society.

College students are the main force of the society in the near future. In summer social practice, college students influence the ordinary people around them with their behaviors, and their positive outlook on life and values bring warmth to people in need of help. At the same time, the volunteer service full of noble spirit can help to create a good social atmosphere promoting mutual help and build a good social atmosphere, and thereby enhancing the spiritual civilization of the whole society to promote the development of a harmonious society.

\section{The Value of College Students' Volunteer Service in Communities}

The value of summer social practice in contemporary society is reflected in the embodiment of social public service and the exercise of college students' social ability. Its value is comprehensive and unique. The specific performance is as follows:

\subsection{Resource Value.}

In recent years, China's labor force continues declining in cities; partly as a result, the corresponding social service cannot keep up with the overall trend of social development, which is mainly reflected in the lack of adequate facilities, low service level and the serious shortage of service personnel [2].As the number of college students in China is increasing year by year, the number of college students participating in summer social practice is also increasing. This enlarges the social service group, provides adequate human resources, effectively protects the smooth progress of social services and fills the loopholes that impede the development of community services caused by the insufficient number of volunteers.

\subsection{Personal Values.}

The participation of college students in summer social practice will help them to practice in the real society and accumulate social practical experience, so as to lay a good foundation for the future graduation. College students spend most of their time in the campus and they generally have low acceptance of new things outside the school. At the same time, as the theoretical education is much more than practical education in China's colleges and universities, college students usually lack practical experience and show great shortcomings in actual operations. The fact that they communicate with the real society infrequently makes them difficult to adapt to the needs of society for talents. By participating in summer social practice, college students can exercise their language expression ability, practical ability, planning and design ability and other abilities that they cannot exercise in the school. Furthermore, college students can promote their moral cultivation to a certain extent and improve their personality charm through the completion of summer social practice.

\subsection{Educational Value.}

As "unusually lucky persons", most college students seem to be pompous and extremely arrogant in real life and learning. This is particularly evident on post-90s college students, because most of them are the only child in their family who are generally spoiled and pampered. The organized and disciplined summer social practice will make the ideological and moral education mode of universities more balanced, which will play an important role in training college students' social service ability and social adaptability [3].

From a comprehensive perspective, summer social practice not only has a certain impact on the society and college students themselves, but also is also helpful to the innovation of ideas and models of social practice. The participation of college students in summer social practice can perfect the 
development mode of social practice activities and transform the development ideas, and at the same time, it is a good exercise for students' own development.

\section{Improving the Mechanism of Summer Social Practice to Promote College Students' Comprehensive Qualities}

\subsection{Expanding the Summer Practice Base and Making Use of Form Innovation to Facilitate the Practice of College Students.}

The content and form of social practice that college students participate in at present are very similar to general social service and the actual practice effect often does not come up to expectations. As a result, the public do not show much recognition and support for college students' participation in summer social practice. This is mainly manifested in the fact that they underestimate the significance and value of college students' summer social practice, thereby reducing their support in site, facilities, opportunities and other aspects for summer social practice; a lot of enterprises and communities even do not let college student carry out social practice in area under their jurisdiction; this is a problem needs more attention of the public and schools and specific solutions [4].

Expanding summer practice base requires schools and society to work together to integrate existing resources, change traditional concepts and introduce market competition mechanism continuously. Schools can vigorously publicize summer social practice through various channels, so that the society and enterprises can correctly understand the important role and positive significance of social practice of college students, and then they will make use of their own resources to improve the summer practice platform for college students. For example, the work-study program, internship entrepreneurship, community voluntary service and other forms can be used to expand different channels, so as to facilitate the comprehensive practice of college students.

\subsection{Carrying Out Education and Training Activities Rationally to Enrich the Content of Service.}

School is an important comprehensive learning place for college students. School education plays an irreplaceable role for college students, and therefore, the school's organization or education should actively connect with social practice activities in which that college students participate. Colleges and universities need to actively carry out education and training activities, including playing videos with teaching and guiding significance, delivering knowledge through related books and giving student targeted interpretation by teachers or volunteers with rich experience, so as to achieve the normalization of social practice activities. In addition, colleges and universities should communicate with people in charge of communities or enterprises to understand the needs for social practice timely, so that the content and form of services can be continuously innovated rather than just focus on traditional activities.

School plays an irreplaceable role in education and thus it generally has comprehensive effects on imparting the knowledge and theory of social practice. Qualified schools can invite senior sociology scholars and social practice researchers to teach students knowledge and skills regularly, achieving the popularization of knowledge related to summer social practice through interactive teaching and experiential teaching. Schools with poor conditions can teach the knowledge of social practice through remote video connections or organizing students to watch related teaching videos. At the same time, different schools should actively organize their students to exchange of experience and cooperate with each other. The corresponding experience exchanges can clarify their similarities and shortcomings. This will help schools learn from each other to expand the contents of social practice and achieve the overall improvement of summer social practice, and thereby give full play to the role of schools in social practice education.

\subsection{Providing Financial Support for College Students' Summer Social Practice.}

Funds play an important role in the development of social practice. In terms of the incomplete relevant policy of financial support of social practice at present, schools should actively enhance their coordination with various departments, because the lack of funds will hinder corresponding service projects, reduce the efficiency of college students' practical activities and impede the full realization 
of the effective utilization of service resources [5].Funds will have an important impact on the long-term planning of college students' social practice. In the future, social support and government support will be the main fund source for college students' social practice, and this kind of financial support is also stable and powerful. The form of funding can be the fund-raising or the establishment of a social practice fund for college students, and the construction of social practice can be further improved through the corresponding financial support. And meanwhile, it is also a good incentive for college students. The corresponding financial support will make it possible that college students can pay their attention mainly on how to carry out social practice rather than disrupt their activities because of lack of funds or other reasons, which will also make college students' social practice more continuous and effective.

\subsection{Constantly Learning and Cultivating Spirit of Dedication to Promote Social Practice.}

The participation of college students in social practice requires their own strength and reserve of corresponding knowledge. In the face of the increasingly high requirements of social practice, college students should actively improve their knowledge level and participation ability. They can deepen the comprehensive understanding of social practice through videos, books, reports or other kinds of materials about corresponding activities. At the same time, colleges and universities should also actively carry out relevant knowledge lectures or forums about social practice to help students study and master social practice theories and methods. The constant education of social practice knowledge will have a positive impact on college students' psychology education and help them form good moral characters. They can also learn about the volunteer service standards through the learning of actual cases, which will have an important significance to standardize their actual social practice behaviors in the future.

College students can help to standardize the social practice by learning advanced social practice knowledge and increasing the corresponding ability. At the same time, college students should set up lofty ideals and beliefs and develop their behavior habits to participate in social practice actively. Only by continuously learning can students accept the latest ideas about social practice to facilitate the comprehensive development of social practice.

\subsection{Adjusting the Mentality to Improve the Participation of College Students.}

Due to the influence of various factors, the overall enthusiasm of college students is not very high in the summer social practice. For the college students, the lack of rational cognition of social practice is one of the main reasons for the low participation rate. Besides, many college students have not realized this positive significance yet. They only take summer social practice as a task or a necessary exercise method while not pondering over the meaning of social practice itself. In this sense, they do not lay their mindset in the right place. To enhance the participation rate of college students' summer social practice, it is needed to transform the mindset of college students from passive and compulsive participation to active and enjoyable participation which can satisfy their psychological needs. Actively participating in social practice can make college students understand their own social values. Through continuous participation in positive and health activities, college students will be able to better perfect their optimistic attitude and cultivate their personality and comprehensive ability to achieve the high consistency of emotion and intention, and thereby fundamentally eliminating the negative effects of laziness and passivity on their summer social produced by practice at present.

\section{Conclusion}

To sum up, the participation of college students in summer social practice is of great significance for the promotion of their comprehensive qualities, while it has become an important problem in the perfection of college students' social practice to increase the participation rate and strengthen social support and assistance. After analyzing the meaning and value of summer social practice to the promotion of students' comprehensive qualities, the author expounded how to strengthen the students' summer social practice at the practical level, hoping this research can provide realistic thinking for schools and the society to grasp students' summer social practice more accurately. This will be an important way for the innovation of education concept and education methods in higher education, 
and also an effective way to strengthen the ideological and behavioral ability of contemporary college students.

\section{Acknowledgements}

The research is funded by the foundation of the Research Center for the development of agricultural and valley development in China, the key research base of the humanities and Social Sciences in Hubei.

\section{References}

[1]. Lain Xin. The Lost Summer Social Practice-- Thinking about the Current Situation of College Students' Practical Activities in Summer Vacation [J]. Education Modernization, 2016, 3 (03): 240-242.

[2]. Chang Hailing. Research on the Status Quo of Summer Social Practice for College Students and Countermeasures [D]. Huazhong Agricultural University, 2014.

[3]. Zhao Bezique. Study of the Reform of College Students' Social Practice in Summer Vacation -In the Way of Combining with the Practice of Ideological and Political Theory [J]. China Adult Education, 2013 (11): 34-36.

[4]. Qian Mu. The Innovation Mode of College Students' Summer Social Practice -- Taking Chengdu University of Technology as an Example [J]. Journal of Chengdu University of Technology (social science edition), 2011, 19 (05): 91-94.

[5]. Coo xueya, mu wee. Exploration of the long-term mechanism of college students' summer social practice -- taking jinxing university as the study case [j]. Journal of huaihai institute of technology (social science edition), 2011, 9 (06): 122-124. 